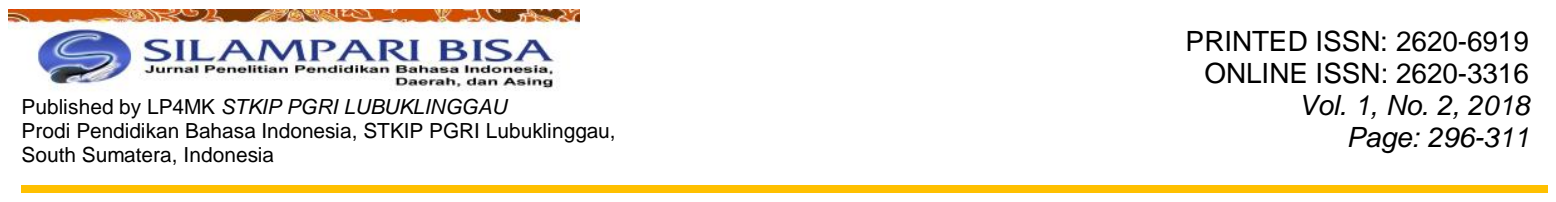

\title{
GAYA BAHASA PERTENTANGAN DALAM NOVEL PERAHU KERTAS KARYA DEWI LESTARI
}

\author{
Inda Puspita Sari \\ Program Studi Pendidikan Bahasa dan Sastra Indonesia, STKIP PGRI Lubuklinggau \\ Jalan Mayor Toha, Kelurahan Air Kuti, Kota Lubuklinggau, Indonesia \\ Email: indashop21@gmail.com
}

\begin{abstract}
Abstrak
Tujuan penelitian ini untuk mendeskripsikan gaya bahasa pertentangan yang terdapat dalam novel Perahu Kertas Karya Dewi Lestari. Penelitian ini menggunakan metode penelitian deskriptif kualitatif terhadap dokumen berbentuk novel Perahu Kertas karya Dewi Lestari sebagai sumber datanya. Teknik pengumpulan data pada penelitian ini dengan teknik pustaka, teknik simak, dan catat. Teknik analisis data dimulai dengan pengumpulan data, reduksi data, penyajian data, dan penarikan kesimpulan. Berdasarkan hasil analisis novel Perahu Kertas yang telah dilakukan, diketahui bahwa terdapat gaya bahasa pertentangan yang didominasi dengan penggunaan gaya bahasa hiperbola dan dilengkapi oleh gaya bahasa litotes, oksimoron, paranomasia, ivendo, klimaks, antiklimaks, sarkasme, antifrasis, paradoks, ironi, sinisme, dan hiperbaton. Gaya bahasa pertentangan yang diciptakan oleh Dewi Lestari dalam novel Perahu Kertas, menunjukkan bahwa permainan penggunaan gaya bahasa sangat penting dalam membangun sebuah novel.
\end{abstract}

Kata kunci: gaya bahasa pertentangan, novel

\section{CONTRADICTORY LANGUAGE STYLE IN THE PERAHU KERTAS NOVEL BY DEWI LESTARI}

\begin{abstract}
The purpose of this study was to describe the contradictory language style found in the Perahu Kertas novel by Dewi Lestari. This study used a descriptive qualitative research method for Dewi Lestari's novel paper boat as the data source. Data collection techniques in this study with library techniques, refer technique, and note. Data analysis techniques begin with data collection, data reduction, data presentation, and conclusion drawing. Based on the results of the analysis of the Perahu Kertas novel that has been done, it is known that there are opposing language styles that are dominated by the use of hyperbolic language styles and are equipped with litotes, oksimoron, paranomasia, ivendo, climax, anticlimactic, sarcasm, antiphasis, paradox, irony, cynicism. and hyperbaton. The contradictory language style created by Dewi Lestari in the Perahu Kertas novel shows that the game of using language styles is very important in building a novel.
\end{abstract}

Keywords: contradictory language style, novel 


\section{A. Pendahuluan}

Karya sastra sebagai hasil ciptaan dari kreativitas manusia yang bersifat otonom dan imajinasi serta mempunyai koherensi antara unsur-unsurnya sehingga menghasilkan nilai dan manfaat Nurgiyantoro (2005:10). Karya sastra juga memiliki kaitan erat dengan manusia, selain pengarangnya manusia, tidak sedikit karya sastra yang ide pokoknya berasal dari kehidupan manusia. Melalui karya sastra pengarang mampu dengan bebas berbicara tentang kehidupan yang dialami oleh manusia dalam berbagai peraturan dan beberapa norma dalam interaksinya dengan lingkungan, sehingga dalam karya sastra terdapat makna tertentu tentang kehidupan (Muhtadin \& Murniasih, 2018:155).

Dalam karya sastra juga harus mampu memiliki nilai keindahan dan manfaat yang tidak dapat dipisahkan dengan pengajaran bahasa dan sastra karena keduanya saling membangun, terutama dalam pengajaran bahasa selalu menggunakan karya sastra sebagai objek utamanya dalam menjelaskan fungsi dan ciri bahasa tersebut (Noermanzah, 2017:28). Karya sastra terbagi menjadi dua yaitu karya sastra lama dan karya sastra baru. Karya sastra lama terdiri atas pantun, gurindam, satire, dan lain sebagainya. Sedangkan karya sastra baru, terbagi menjadi beberapa diantaranya novel, cerpen, puisi, dan lain sebagainya.

Karya sastra yang berbentuk novel adalah karya fiksi yang dibangun melalui berbagai unsur intrinsiknya. Unsur-unsur tersebut sengaja dipadukan pengarang dan dibuat mirip dengan dunia yang nyata lengkap dengan peristiwa-peristiwa di dalamnya, sehingga nampak seperti sungguh ada dan terjadi. Sesuai dengan pernyataan Semi (2003:32), novel adalah karya fiktif yang berusaha menggambarkan atau melukiskan kehidupan tokoh-tokohnya dengan menggunakan alur. Sejalan dengan Kosasih (2003:223), menjelaskan bahwa novel adalah prosa rekaan yang menyuguhkan tokoh dan menampilkan serangkaian peristiwa serta latar secara tersusun. Novel sebagai karya imajinatif mengungkapkan aspek-aspek kemanusiaan yang mendalam dan menyajikannya secara halus.

Berdasarkan pendapat di atas, novel adalah suatu cerita prosa fiktif yang mempunyai panjang tertentu, di dalamnya terdapat unsur-unsur intrinsik dan semuanya bersifat imajiner. Meskipun demikian, di dalam sebuah novel 
mengangkat sebuah cerita kehidupan yang diidealkan karena menampilkan kehidupan manusia secara mendalam dan kejadiannya pun luar biasa, serta disajikan secara halus. Unsur inilah yang akan menyebabkan novel hadir. Unsur intrinsik sebuah novel adalah unsur yang secara langsung membangun sebuah cerita. Keterpaduan berbagai unsur intrinsik ini akan menjadikan sebuah novel yang sangat bagus. Kemudian, untuk menghasilkan novel yang bagus juga diperlukan pengolahan bahasa. Bahasa merupakan sarana atau media untuk menyampaikan gagasan atau pikiran pengarang yang akan dituangkan sebuah karya sastra, salah satunya novel.

Setiap pengarang dalam membuat karya akan memperlihatkan penggunaan bahasa dengan ciri-ciri dan pola-pola tersendiri yang membedakan dengan pengarang lainnya. Penggunaan bahasa yang khas dalam karyanya tentu akan memperlihatkan ciri-ciri individualisme, orisinalitas, dan gaya masing-masing pengarang. Salah satu kekhasan penggunaan bahasa tersebut antara lain diperlihatkan oleh salah seorang penulis muda yang berbakat yaitu Dewi Lestari, melalui novelnya Perahu Kertas.

Keanekaragaman dan gaya bahasa Dewi Lestari melalui novel Perahu Kertas, sangat perlu dan menarik untuk diteliti. Novel tersebut sarat dengan konflik, ditulis dengan gaya realis bertabur metafora yang berani, tidak biasa, dan tidak terduga, namun amat memikat. Novel ini begitu edukatif dikarenakan bisa banyak belajar dari novel ini. Mulai dari bagaimana kita harus tetap semangat dalam meraih mimpi-mimpi. Novel Perahu Kertas ini juga penuh akan nilai-nilai positif serta makna kehidupan yang tidak hanya bercerita tentang remaja pada umumnya, tetapi bercerita tentang dinamika kehidupan empat orang remaja serta korelasinya dengan lingkungan internal. Dengan pelukisan latar waktu dan tempat yang sangat mendetail, tetapi tidak berlebihan, menambah daya tarik dari novel ini dan membuat seolah pembaca ikut terlibat di dalamnya.

Novel ini mengulas tema persahabatan yang sarat akan konflik yang menghanyutkan untuk para pembacanya. Dikemas dengan gaya bahasa yang lugas dan ringan serta sesuai dengan kondisi masyarakat sekarang menjadikan novel ini dapat mudah dimengerti dan diniikmati oleh pembaca pada berbagai 
lapisan usia. Novel Perahu Kertas sangatlah beragam dalam penggunaan gaya bahasanya.

Menurut Keraf (2005:112), gaya bahasa merupakan bentuk retorik dengan penggunaan kata-kata dalam menulis untuk meyakinkan atau mempengaruhi penyimak dan pembaca. Sedangkan menurut Tarigan (2009:4), gaya bahasa merupakan bahasa indah yang digunakan untuk meningkatkan efek dengan jalan memperkenalkan serta membandingkan suatu benda atau hal tertentu dengan benda atau hal lain yang lebih umum. Gaya bahasa merupakan suatu cara mengungkapkan melalui susunan perkataan yang terjadi karena perasaan yang timbul atau hidup dalam hati penulis, yang menimbulkan suatu perasaan tertentu dalam hati pembaca karena menggunakan bahasa yang khas yang membuat suatu karya sastra bernilai hidup, berjiwa serta indah, menarik, dan mudah dipahami.

Berdasarkan pendapat ahli di atas, dapat disimpulkan bahwa gaya bahasa merupakan pemilihan kata atau diksi dalam karya sastra, biasanya dicirikan dengan penggunaan bahasa indah yang digunakan untuk meningkatkan efek dengan jalan memperkenalkan serta membandingkan suatu benda atau hal tertentu dengan benda atau hal lain yang lebih umum. Gaya bahasa yang dimaksud dalam penelitian ini adalah pemakaian gaya bahasa pertentangan yang meliput hiperbola, litotes, oksimoron, ironi, paranomasia, inuendo, klimaks, antiklimaks, sarkasme, dan antifrasis. Bahasa yang digunakan untuk mengisahkan cerita inilah yang membuat novel Perahu Kertas menarik untuk dianalisis. Analisis terhadap novel Perahu Kertas dibatasi pada penggunaan gaya bahasa, karena setelah membaca novel Perahu Kertas, ditemukan ada banyak gaya bahasa yang digunakan pengarang, salah satunya gaya bahasa pertentangan.

Hasil dalam penelitian ini relevan dengan penelitian yang dilakukan oleh Amelia (2010) dalam skripsi yang berjudul Analisis Gaya Bahasa dan Nilai-Nilai Pendidikan Novel Sang Pemimpi Karya Andea Hirata. Dalam skripsi tersebut diketahui bahwa penelitian yang dilakukan menggunakan metode analisis isi dan meneliti keseluruhan gaya bahasa serta nilai-nilai pendidikan. Persamaan dengan penelitian relevan ini sama-sama meneliti sebuah gaya bahasa pada sebuah 
novel. Perbedaannya terdapat pada metode yang digunakan, novel yang dianalisis dan gaya bahasa yang dianalisis berbeda dengan penelitian yang ditulis.

Penelitian relevan yang selajutnya yaitu penelitian yang dilakukan oleh Wahyudi (2011) dalam skripsi yang berjudul Analisis Gaya Bahasa pada Novel Sang Pencerah Karya Akmal Nasery Basral. Hasil penelitian relevan ini mendeskripsikan hubungan gaya bahasa dengan tokoh utamanya. Persamaan dalam penelitian relevan ini yaitu sama-sama menanalis gaya bahasa pada novel. Perbedaan yang terdapat pada penelitian yang dilakukan penulis dengan penelitian yang dilakukan oleh Wahyudi adalah pada cara analisis data menggunakan metode padan dan teknik yang digunakan menggunkan teknik pilar unsur penentu (PUP). Penelitian relevan membahas dan mendeskripsikan hubungan gaya bahasa dengan tokoh utamanya, sedangkan peneliti berfokus pada gaya bahasa pertentangan saja.

Hasil penelitian relevan juga pernah dilakukan oleh Violita, dkk. (2013:1) tentang analisis gaya bahasa dalam novel Supernova 2 "Akar" karya Dewi Lestari. Hasil penelitiannya berupa gaya bahasa yang digunakan oleh Dewi Lestari lebih didominasi oleh gaya bahasa pertentangan dengan jenis metafora dan hiperbola. Penelitian ini sama-sama meneliti novel karya Dewi Lestari dan perbedaannya bahwa peneltian yang dilakukan terletak pada data novelnya yaitu novel Perahu Kertas.

Dari beberapa hasil penelitian relevan di atas, menujukkan bahwa gaya bahasa pertentangan yang terdapat dalam novel Perahu Kertas Karya Dewi Lestari belum diteiti. Untuk itu, dalam penelitian ini akan menjawab permasalahan "Bagaimanakah gaya bahasa pertentangan yang terdapat dalam novel Perahu Kertas Karya Dewi Lestari?" Dengan tujuan mampu memberikan pemahaman tentang karakteristik gaya bahasa pertentangan yang digunakan oleh Dewi Lestari dalam novelnya Perahu Kertas. 


\section{B. Metode Penelitian}

Metode yang digunakan dalam penelitian adalah metode deskriptif kualitatif. Metode ini bersifat deskriptif sehingga datanya berupa kalimat yang dianalisis dari segi kegramatikalannya dengan menggunakan teori atau pendekatan tertentu. Dalam penelitian ini penulis menggunakan rancangan struktural, maksudnya meneliti dan memberikan serta menerangkan segi-segi tertentu mengenai struktur bahasa berdasarkan fakta-fakta kebahasan yang dijumpai dalam pertuturan (Subroto, 2002:32).

Pemilihan jenis penelitian deskriptif kualitatif ini disesuaikan dengan permasalahan yang dibahas dan tujuan penelitian. Untuk membahas permasalahan dan mencapai tujuan penelitian, penelitian deskriptif kualitatif menggunakan strategi berpikir fenomenologis yang bersifat lentur dan terbuka serta menekankan analisisnya secara induktif dengan meletakkan data penelitian bukan sebagai alat pembuktian, tetapi sebagai modal dasar untuk memahami fakta-fakta yang ada (Sutopo, 2007:47). Fakta yang dideskripsikan adalah pemakaian gaya bahasa yang meliputi perbandingan, pertentangan, pertautan, dan perulangan yang terdapat dalam novel Perahu Kertas. Hal ini menunjukkan bahwa penelitian ini diarahkan untuk memperoleh deskripsi yang objektif dan akurat dari novel Perahu Kertas karya Dewi Lestari.

Data dalam penelitian ini adalah gaya bahasa pertentangan yang terdapat dalam novel Perahu Kertas karya Dewi Lestari. Sedangkan sumber data dalam penelitian ini adalah novel Perahu Kertas karya Dewi Lestari, dengan tanggal terbit Agustus 2009, penerbit Bentang Pustaka, dengan jumlah halaman sebanyak 444 halaman. Teknik pengumpulan data yang dipergunakan dalam penelitian ini ialah teknik pustaka, teknik simak, dan catat. Teknik pustaka yaitu pencarian data dengan menggunakan sumber-sumber tertulis yang mencerminkan pemakaian bahasa sinkronis (Subroto, 2002:42). Kemudian, teknik analisis data yang digunakan adalah analisis mengalir. Analisis mengalir ini terdiri dari alur kegiatan yang terjadi secara bersamaan, yaitu pengumpulan data, reduksi data, penyajian data, dan penarikan kesimpulan. Empat langkah kegiatan ini terjadi secara bersamaan dan saling menjalin, baik sebelum, selama, dan sesudah pengumpulan data secara paralel (Miles \& Huberman, 2002:13). 


\section{Hasil Penelitian dan Pembahasan}

\section{Hasil Penelitian}

Penelitian ini difokuskan pada analisis jenis gaya bahasa pertentangan dalam novel Perahu Kertas Karya Dewi Lestari. Hasil analisis data menunjukkan bahwa gaya bahasa pertentangan terdapat gaya bahasa perbandingan terdapat 25 jenis, 13 jenis diantaranya digunakan dalam novel ini seperti hiperbola terdapat 120, litotes 6 , oksimoron 1, paranomasia 4, ivendo 5, klimaks 3, antiklimaks 11 , sarkasme 2, antifrasis 4, paradoks 4, ironi 2, sinisme 2, dan hiperbaton 1. Berikut dapat ditunjukkan dalam tabel rekapitulasi data penggunaan gaya bahasa dalam novel Perahu Kertas karya Dewi Lestari.

Tabel 1. Gaya Bahasa Pertentangan dalam Novel Perahu Kertas Karya Dewi Lestari

\begin{tabular}{|clc|}
\hline No. & \multicolumn{1}{c|}{ Gaya Bahasa } & Jumlah \\
\hline 1 & Hiperbola & 120 \\
2 & Litotes & 6 \\
3 & Oksimoron & 1 \\
4 & Paranomasia & 4 \\
5 & Inuendo & 5 \\
6 & Klimaks & 3 \\
7 & Antiklimaks & 11 \\
8 & Sarkasme & 2 \\
9 & Antifrasis & 4 \\
10 & Ironi & 2 \\
11 & Sinisme & 2 \\
12 & Paradok & 4 \\
13 & Hiperbaton & 1 \\
\hline
\end{tabular}

Berdasarkan tabel gaya bahasa pertentangan novel Perahu Kertas Karya Dewi Lestari, diketahui bahwa gaya bahasa pertentangan pada bagian hiperbola yang paling dominan digunakan dalam novel Perahu Kertas Karya Dewi Lestari.

\section{Pembahasan}

Novel Perahu Kertas karya Dewi Lestari menceritakan mengenai Kugy dan Keenan dengan didominasi dengan penggunaan gaya bahasa yang bervariasi, tetapi didominasi oleh hiperbola. Cerita yang dijalin menggunakan gaya bahasa yang bervariasi mampu memberikan daya tarik tersendiri bagi pembaca. Hal ini sesuai dengan fungsi gaya yaitu mampu meyakinkan atau mempengaruhi pembaca dengan bahasa tulis yang dikemasnya (Keraf (2005:112). Selain itu, gaya bahasa pertentangan yang dihadirkan oleh Dewi Lestari dalam novel Perahu 
Kertas juga sesuai pendapat Tarigan (2009:4), bahwa gaya bahasa merupakan bahasa indah yang digunakan untuk meningkatkan efek dengan jalan memperkenalkan serta membandingkan suatu benda atau hal tertentu dengan benda atau hal lain yang lebih umum. Hal ini hampir sama dengan gaya bahasa pertentangan yang digunakan Dewi Lestari didominasi dengan penggunaan gaya bahasa hiperbola dan dilengkapi oleh gaya bahasa litotes, oksimoron, paranomasia, ivendo, klimaks, antiklimaks, sarkasme, antifrasis, paradoks, ironi, sinisme, dan hiperbaton.

Kemudian gaya bahasa yang digunakan dalam novel Perahu Kertas hampir sama dengan hasil penelitian yang dilakukan oleh Violita, dkk. (2013:1) yang juga meneliti novel karya Dewi Lestari, yaitu pada novel Supernova 2 "Akar" karya Dewi Lestari. Hasil penelitiannya berupa gaya bahasa yang digunakan oleh Dewi Lestari juga didominasi oleh gaya bahasa pertentangan, tetapi bukan hanya didominasi oleh gaya bahasa hiperbola juga didominasi oleh gaya bahasa metafora.

Novel Perahu Kertas menceritakan dua anak manusia yang dapat diibaratkan seperti bumi dan langit (Lestari, 2009). Kugy memiliki penampilan berantakan, namun ia memiliki imajinasi yang tinggi. Sedangkan Keenan, merupakan sosok yang cerdas dan pelukis hebat dan artistik. Saat keduanya bertemu, keduanya menjadi semakin dekat. Namun, apa boleh buat? Kugy telah memiliki seorang pujaan hati yang tidak mudah ia tinggalkan. Dalam hati Keenan, terbesit rasa cinta itu namun ia juga berusaha untuk menampiknya. Wanda dan Keenan seperti sosok yang senasib. Keduanya berbakat menjadi pelukis, namun kedua orang tua mereka jugalah yang tidak setuju karena orang tua mereka berpendapat bahwa lukisan tidak bisa menghasilkan uang untuk hidup.

Novel Perahu Kertas ini mengulas tema persahabatan yang sarat akan konflik yang menghanyutkan untuk para pembacanya. Dikemas dengan gaya bahasa yang lugas dan ringan serta sesuai dengan kondisi masyarakat sekarang menjadikan novel ini dapat mudah dimengerti dan diniikmati oleh pembaca pada berbagai lapisan usia. Keanekaragaman gaya bahasa yang digunakan untuk mengisahkan cerita inilah yang membuat novel Perahu Kertas menarik. Berikut pembahasan khusus mengenai gaya bahasa pertentangan yang terdapat dalam 
novel Perahu Kertas karya Dewi Lestari. Gaya bahasa pertentangan di sini terdapat 13 jenis yang akan dibahas di bawah ini.

a. Hiperbola

Pada gaya bahasa jenis hiperbola, sangat mendominasi yang terdapat 120 gaya bahasa hiperboala yang digunakan pada novel ini. Berikut beberapa kutipan hiperbola yang terdapat pada novel Perahu Kertas.

Keenan tidak tahu persis apa yang terjadi. Bagaimana mungkin orangtuanya, sumber dari bakat melukis yang mengalir darahnya. (Hal. 2) (002).

Kutipan di atas dikategorikan sebagai gaya bahasa hiperbola, karena berlebihan menggambarkan bakat yang diperoleh dari orang tuanya dapat mengalir dalam darahnya. Contoh berikutnya dapat dilihat pada kutipan berikut.

Dua ribu lebih hari berlalu dan Keenan merasa enam tahun sesingkat kedipan mata. (Hal. 3) (003).

Kalimat tersebut dapat dikategorikan sebagai gaya bahasa hiperbola karena kalimat "enam tahun sesingkat kedipan mata" terlalu berlebihan, karena menjalani waktu enam tahun merupakan waktu yang cukup lama tidaklah sesingkat sekali mengedipkan mata. Berikut contoh lain penggunaan gaya bahasa hiperbola.

Oma tersenyum. Keriput tidak menyusutkan kecantikan dari wajahnya.

(Hal. 3) (004).

Kutipan di atas dikategorikan sebagai gaya bahasa hiperbola, karena berlebihan menganggap keriput karena usia tidak dapat mengurangi kecantikan Oma yang sudah sangat tua. Dari beberapa gaya bahasa hiperbola yang digunakan memberikan informasi bahwa Dewi Lestari sangat piawai dalam mengemas bahasa secara hiperbola sehingga peristiwa yang diceritakan mampu memberikan keyakinan kepada pembacanya.

b. Litotes

Pada cupilkan di bawah ini menunjukkan adanya gaya bahasa pertentangan litotes. Gaya bahasa litotes merupakan gaya bahasa yang mengandung pernyataan dikurangi (dikecilkan) dari makna yang sebenarnya. Hal ini dapat dilihat pada kutipan berikut: 
Mata Kugy berkaca-kaca. Seribu terima kasih seolah tak cukup baginya. (Hal. 340) (001).

Kalimat di atas dikategorikan sebagai gaya bahasa litotes karena kalimat "Seribu terima kasih seolah tak cukup baginya" merupakan penggambaran seseorang dalam merendahkan diri. Mak Cik dalam kalimat di atas merasa bahwa dengan seribu ucapan terima kasih pun tidak akan cukup untuk menembus semuanya. Berdasarkan temuan dan analisis gaya bahasa di atas, dapat disimpulkan bahwa gaya bahasa litotes yang terdapat dalam novel Perahu Kertas juga memberikan efek pengaruh bagi pembaca untuk menjadi semakin meyakinkan atas cerita yang disampaikan.

c. Oksimoron

Pada subjudul judul Pindah ke Bandung dalam novel Perahu Kertas, ditemukan gaya bahasa oksimoron adalah suatu acuan yang berusaha untuk menggabungkan kata-kata untuk mencapai efek yang bertentangan. Hal ini dapat dilihat pada kutipan berikut:

Jika sebelum kuda-kuda itu datang ia jadi pendiam dan giat bekerja, sekarang ia jadi lebih pendiam dan malas pendiam. (Hal. 11) (001).

Kalimat di atas dikategorikan sebagai gaya bahasa oksimoron karena adanya suatu acuan yang berusaha menggabungkan kata-kata untuk mencapai efek yang bertentangan yaitu kata tersebut adalah "giat bekerja dan malas pendiam".

Pada judul Mother Alien, ditemukan gaya bahasa oksimoron adalah suatu acuan yang berusaha untuk menggabungkan kata-kata untuk mencapai efek yang bertentangan. Berdasarkan temuan dan analisis gaya bahasa di atas, dapat disimpulkan bahwa gaya bahasa oksimoron juga terdapat dalam novel Perahu Kertas dalam membangun daya pengaruh bagi pembaca.

d. Paranomasia

Pada subjudul Hunusan Pedang Es dalam novel Perahu Kertas karya Dewi Lestari, ditemukan gaya bahasa paranomasia yang berfungsi sebagai gaya bahasa yang berisi penjajaran kata-kata yang berbunyi sama, tetapi bermakna lain. Hal ini dapat dilihat pada kutipan berikut: 
"Daunnya ditaruh di sini," Candy menunjuk wadah kerucut. "bakar, terus asapnya diisap dari sini," lanjutnya sambil menunjukkan sobekan di ujung. Kotak ini resmi jadi Candy. (Hal. 49) (001).

Pada kutipan kalimat di atas merupakan gaya bahasa paranomasia karena kata "Candy" memiliki kesamaan bunyi, tetapi memiliki arti yang berbeda. "Candy" pada ungkapan "Candy menunjuk wadah kerucut" merupakan nama satu di antara tokoh di dalam novel, sedangkan "Candy" pada ungkapan "kotak ini resmi jadi Candy" memiliki arti permen yang berbentuk kaki. Berdasarkan temuan dan analisis gaya bahasa di atas, dapat disimpulkan bahwa gaya bahasa paranomasia yang terdapat dalam novel Perahu Kertas juga memberikan warna tersendiri yang menjadikan cerita yang disajikan menjadi semakin nyata.

e. Inuendo

Pada subjudul Bumi pun Berputar dalam novel Perahu Kertas karya Dewi Lestari, ditemukan gaya bahasa inuendo sebagai gaya bahasa yang berupa sindiran dengan mengecilkan kenyataan yang sebenarnya. Hal ini dapat dilihat pada kutipan berikut:

“Walau dengan otak berkabut sehabis minum Cap Tikus." (Hal. 254) (001).

Kalimat di atas merupakan gaya bahasa inuendo karena kata "mabuk" diungkapan dengan frasa "otak berkabut", hal tersebut mengecilkan-ngecilkan keadaan yang sesungguhnya. Berdasarkan temuan dan analisis gaya bahasa di atas, dapat disimpulkan bahwa gaya bahasa inuendo yang terdapat dalam novel Perahu Kertas juga membantu dalam menjadikan cerita tersebut semakin menarik.

\section{f. Klimaks}

Pada subjudul Mencari Ketulusan dalam novel Perahu Kertas karya Dewi Lestari, ditemukan gaya bahasa klimaks atau anabasis sebagai gaya bahasa yang terbentuk dari beberapa gagasan yang berturut-turut dan semakin meningkat kepentingannya. Hal ini dapat dilihat pada kutipan berikut:

"Aku belajar hampir segalanya, mulai dari belajar merangkak, bicara, sampai pipis sendiri." (Hal. 284) (001).

Kalimat tersebut merupakan gaya bahasa klimaks yang berupa susunan ungkapan yang semakin lama semakin menghebat penekanannya. Penekanan 
tersebut terlihat dari perkembangan kemampuan Kugy mulai dari merangkak, yaitu bergerak dengan bertumpu pada tangan dan lutut, lalu kemampuan tersebut meningkat bisa bicara, lalu meningkat lagi kemampuannya hingga bisa kencing sendiri ke kamar mandi. Berdasarkan temuan dan analisis gaya bahasa di atas, dapat disimpulkan bahwa gaya bahasa klimaks yang terdapat dalam novel Perahu Kertas juga hadir dalam memberikan efek pengaruh dalam meyakinkan pembaca terhadap peristiwa yang diceritakan.

g. Antiklimaks

Pada subjudul Terakhir di Ujung Tahun dalam novel Perahu Kertas karya Dewi Lestari, ditemukan gaya bahasa antiklimaks yang berisi gagasan-gagasan yang berturut-turut semakin berkurang kepentingannya. Hal ini dapat dilihat pada kutipan berikut:

"Tiga puluh detik kubiarkan mereka puas tercengang kagum, sebelum kuajak kelopak mata mereka jatuh menutup, merunut napas dalam satuan delapan detik, sampai akhirnya pikiran mereka menyerah." (Hal. 311) (001).

Kalimat di atas merupakan gaya bahasa antiklimaks yang berupa susunan ungkapan yang semakin lama pernyataannya semakin menurun. Penurunan pernyataan tersebut tampak pada antusiasme yang ditunjukkan oleh pemuda yang mendengarkan kisah perjalanan hidup Keenan. Awalnya pemuda-pemuda tersebut sangat bersemangat mendengarkan cerita Keenan tecengang dan terkagum-kagum, hingga akhirnya mereka merasakan jenuh dan bosan. Berdasarkan temuan dan analisis gaya bahasa di atas, dapat disimpulkan bahwa gaya bahasa antiklimaks yang terdapat dalam novel Perahu Kertas juga memberikan efek kepada pembaca dalam menikmati setiap peristiwa yang diceritakan.

h. Sarkasme

Pada subjudul Karya Bersama dalam novel Perahu Kertas karya Dewi Lestari, ditemukan gaya bahasa sarkasme yang mengandung sindiran pedas. Hal ini dapat dilihat pada kutipan berikut:

“... Ibu-mu beranak di kandang babi pun aku tak peduli!” (Hal. 362) (001).

Ungkapan di atas merupakan sindiran yang terdengar kasar dan tidak sopan yang dituturkan oleh Kugy kepada Keenan. Kata "beranak" terlihat tidak 
sopan, sehingga digolongkan dalam gaya bahasa sarkasme. Kata beranak biasa digunakan untuk binatang sedangkan kata yang digunakan untuk manusia adalah melahirkan. Penggunaan frasa "kandang babi" juga terlihat tidak sopan seolah yang melahirkan dan dilahirkan adalah binatang. Berdasarkan temuan dan analisis gaya bahasa di atas, dapat disimpulkan bahwa gaya bahasa sarkasme yang terdapat dalam novel Perahu Kertas berfungsi untuk menekankan suatu informasi yang penting dan berbeda dari informasi yang lain.

i. Ironi

Gaya bahasa ironi juga ditemukan dalam novel Perahu Kertas karya Dewi Lestari, berikut contohnya.

Dalam kamarnya yang bergabung dengan taman bacaan di loteng rumah, Kugy menyusun balok demi balok mimpinya. (Hal. 9) (013).

Kalimat tersebut dapat dikategorikan sebagai gaya bahasa yang menyatakan makna yang bertentangan dengan maksud berolok-olok. Jadi gaya bahasa ironi merupakan gaya bahasa yang bermakna tidak sebenarnya dengan tujuan untuk menyindir. Ironi merupakan gaya bahasa yang menyatakan makna yang bertentangan dengan maksud untuk menyindir. Berdasarkan temuan dan analisis gaya bahasa di atas, dapat disimpulkan bahwa gaya bahasa ironi yang terdapat dalam novel Perahu Kertas bertujuan untuk menekankan informasi yang bermakna menyindir.

j. Sinisme

Dalam novel Perahu Kertas karya Dewi Lestari, juga ditemukan gaya bahasa sinisme, berikut cohtohnya.

Ini namanya! Dia masuk!" Istrinya berseru dengan suara tercekat sambil menunjuk satu nama. (Hal. 11) (015).

Kutipan di atas termasuk gaya bahasa sinisme berupa sindiran yang berbentuk kesangsian yang mengandung ejekan terhadap keikhlasan dan ketulusan hati. Sinisme merupakan gaya bahasa yang mengungkapkan yang bersifat mencemooh pikiran atau ide bahwa kebaikan terhadap pada manusia. Bahasa sinisme lebih kasar dari ironi. Berdasarkan temuan dan analisis gaya bahasa di atas, dapat disimpulkan bahwa gaya bahasa sarkasme yang terdapat 
dalam novel Perahu Kertas memberikan warna dalam menceritakan peristiwa yang berbeda dari peristiwa lain yang bermakna ejekan yang kurang santun.

k. Paradoks

Dalam novel Perahu Kertas karya Dewi Lestari, juga ditemukan gaya bahasa paradoks, berikut cohtohnya.

Hiruk-pikuk kerumunan anak kampung dari pelosok gang berdengung di telinganya. (Hal. 14) (017).

Kalimat tersebut dikategorikan sebagai gaya bahasa paradoks yang mengandung pertentangan yang nyata dengan fakta-fakta yang ada. Jadi, gaya bahasa paradoks merupakan gaya bahasa yang kata-katanya mengandung pertentangan dengan fakta yang ada. Berdasarkan temuan dan analisis gaya bahasa di atas, dapat disimpulkan bahwa gaya bahasa sarkasme yang terdapat dalam novel Perahu Kertas yang berfungsi memberikan efek pengaruh pada pembaca dengan mempertentangkan peritiwa yang seharusnya berdasarkan dengan fakta yang ada.

I. Hiperbaton

Dalam novel Perahu Kertas karya Dewi Lestari, juga ditemukan gaya bahasa hiperbaton, berikut cohtohnya.

Setengah mati Keenan menahan senyum gelinya yang spontan ingin membersit. (Hal. 2) (025).

Kutipan di atas dikategorikan sebagai gaya bahasa hiperbaton yang merupakan sesuatu yang tidak logis. Jadi, gaya bahasa hiperbaton atau histeron proteron merupakan gaya bahasa yang merupakan kebalikan dari sesuatu yang logis. Dalam tulisan ataupun percakapan, dalam menulis ataupun berbicara ada kalanya kita membalikkan sesuatu yang logis, membalikkan sesuatu yang wajar. Berdasarkan temuan dan analisis gaya bahasa di atas, dapat disimpulkan bahwa gaya bahasa hiperbaton yang terdapat dalam novel Perahu Kertas memberikan efek pengaruh kepada pembaca agar ceritanya lebih bervariasi sehingga memberikan rasa penasaran bagi pembaca untuk membaca peristiwa berikutnya. 


\section{Simpulan}

Berdasarkan hasil penelitian dan pembahasan, dapat disimpulkan bahwa novel Perahu Kertas karya Dewi Lestari menggunakan gaya bahasa pertentangan yang didominasi dengan penggunaan gaya bahasa hiperbola dan dilengkapi oleh gaya bahasa litotes, oksimoron, paranomasia, ivendo, klimaks, antiklimaks, sarkasme, antifrasis, paradoks, ironi, sinisme, dan hiperbaton. Gaya bahasa pertentangan yang diciptakan oleh Dewi Lestari dalam novel Perahu Kertas, menunjukkan bahwa permainan penggunaan gaya bahasa sangat penting dalam membangun sebuah novel. Dengan hasil penelitian ini diharapkan gaya bahasa pertentangan yang digunakan oleh Dewi Lestari dapat dijadikan model dalam menulis novel.

\section{Daftar Pustaka}

Amelia, R. N. (2010). Analisis Gaya Bahasa dan Nilai-Nilai Pendidikan Novel Sang Pemimpi Karya Andrea Hirata. Skripsi. Tidak dipublikasikan.

Keraf, G. (2005). Diksi dan Gaya Bahasa. Jakarta: Gramedia.

Kosasih, E. (2003). Ketatabahasaan dan Kesusastraan. Bandung: Yrama Widya.

Lestari, D. (2009). Perahu Kertas. Yogyakarta: Bentang Pustaka.

Miles M. B. \& Huberman, M. (2002). Analisis Data Kualitatif. Jakarta: Universitas Indonesia Press.

Muhtadin, M., \& Murniasih, S. (2018). Moralitas dalam Novel Negeri di Ujung Tanduk Karya Tere Liye. Silampari Bisa: Jurnal Penelitian Pendidikan Bahasa Indonesia, Daerah, dan Asing, 1(1), 155. doi:10.31540/silamparibisa.v1i1.19

Noermanzah, N. (2017). Plot in a Collection of Short Stories "Sakinah Bersamamu" works of Asma Nadia with Feminimism Analysis. Humanus: Jurnal Ilmiah Ilmu-ilmu Humaniora, 16(1), 28. https://doi.org/10.24036/jh.v16i1.7015

Nurgiyantoro, B. (2005). Teori Pengkajian Fiksi. Yogyakarta: Gadjah Mada University Press. 
Semi, A. (2003). Anatomi Sastra. Padang: Angkasa Jaya.

Subroto, D. (2002). Pengantar Metode Penelitian Linguistik Struktural. Surakarta: UNS Press.

Sutopo. (2007). Metode Penelitian. Jakarta: Rineka Cipta.

Tarigan, H. G. (2009). Pengajaran Gaya Bahasa. Bandung: Angkasa.

Violita, V., Effendy C., \& Martono. (2013). Analisis Gaya Bahasa dalam Novel Supernova 2 "Akar" Karya Dewi Lestari. Jurnal Pendidikan dan Pembelajaran, 2(12).

Wahyudi, T. (2011). Analisis Gaya Bahasa pada Novel Sang Pencerah Karya Akmal Nasery Basral. Skripsi. Tidak dipublikasikan. 